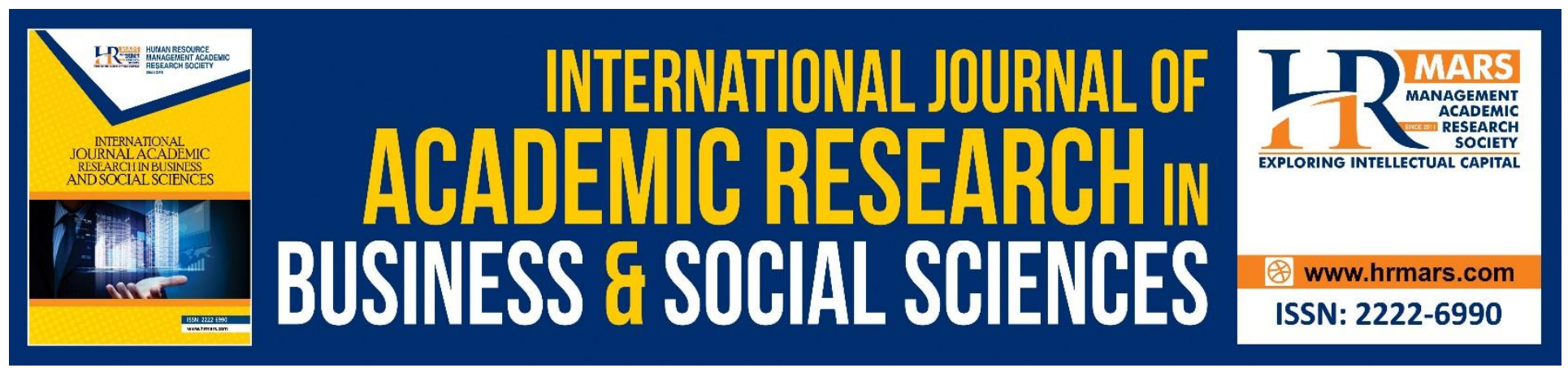

\title{
Linking Knowledge Management and Organizational Performance in Higher Education: Empirical Evidence from Jordanian Universities
}

Hamza Ali Mohammad Alshatnawi, Mazuri Abd Ghani, Anusorn Kunanusorn

To Link this Article: http://dx.doi.org/10.6007/IJARBSS/v8-i12/5073

DOI: $10.6007 /$ IJARBSS/v8-i12/5073

Received: 10 Oct 2018, Revised: 27 Nov 2018, Accepted: 25 Dec 2018

Published Online: 29 Dec 2018

In-Text Citation: (Alshatnawi, Ghani, \& Kunanusorn, 2018)

To Cite this Article: Alshatnawi, H. A. M., Ghani, M. A., \& Kunanusorn, A. (2018). Linking Knowledge Management and Organizational Performance in Higher Education: Empirical Evidence from Jordanian Universities. International Journal of Academic Research in Business and Social Sciences, 8(12), 785-796.

Copyright: (C) 2018 The Author(s)

Published by Human Resource Management Academic Research Society (www.hrmars.com)

This article is published under the Creative Commons Attribution (CC BY 4.0) license. Anyone may reproduce, distribute, translate and create derivative works of this article (for both commercial and non-commercial purposes), subject to full attribution to the original publication and authors. The full terms of this license may be seen

at: http://creativecommons.org/licences/by/4.0/legalcode

Vol. 8, No. 12, 2018, Pg. 785 - 796

http://hrmars.com/index.php/pages/detail/IJARBSS

JOURNAL HOMEPAGE

Full Terms \& Conditions of access and use can be found at http://hrmars.com/index.php/pages/detail/publication-ethics 


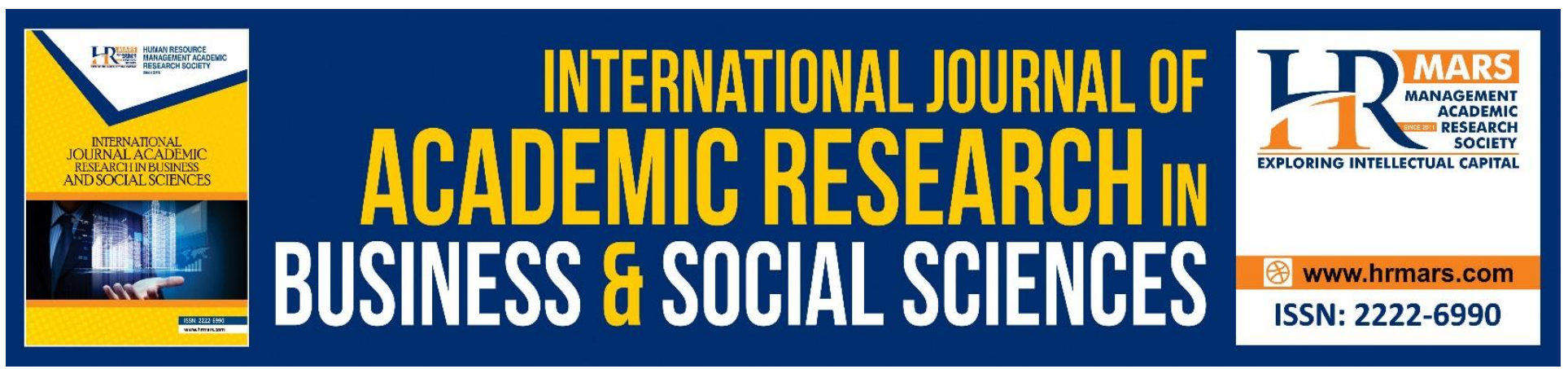

\title{
Linking Knowledge Management and Organizational Performance in Higher Education: Empirical Evidence from Jordanian Universities
}

\author{
Hamza Ali Mohammad Alshatnawi \\ Faculity of Economic \& Management Sciences \\ University Sultan Zainal Abidin, Malaysia \\ Email: amsh28@yahoo.com
}

\section{Mazuri Abd Ghani}

Faculity of Economic \& Management Sciences

Universiti Sultan Zainal Abidin, Malaysia

Corresponding Author Email: mazuri@unisza.edu.my

\author{
Anusorn Kunanusorn \\ Rajamangala University of Technology Lanna, Thailand \\ Email: a_kunanusorn@hotmail.com
}

\begin{abstract}
The motivation behind this examination was to research the connection between Knowledge Management (KM) and Organizational Performance (OP) in Jordanian higher-education institutions (HEls). KM forms included knowledge identification, knowledge acquisition, knowledge storage, knowledge sharing, and knowledge application. In the interim, measures of organizational performance included Job satisfaction and Customer (Students) satisfaction. Based on the theoretical framework, one hypothesis was developed and statistically tested. The examination utilized a crosssectional review procedure. The examples were drawn from Jordanian HEls (public universities) utilizing a stratified irregular testing technique in light of the catalog given by the Ministry of Higher Education and Scientific Research in Jordan. The last number of respondents, associated with this investigation, was 70 respondents from schools (faculties) within 5 public universities. At last, the discoveries from this examination gave experimental proof that KM has a noteworthy and positive effect on organizational performance.
\end{abstract}

Keywords: Knowledge Management, Organizational Performance, Higher Education Institution, Jordan. 


\section{Introduction}

Throughout the world, organizations are now facing a common challenge resulting from rapid changes in the business environment. Organizations need to improve their performance in order to gain sustainable competitive advantages to survive in today's competitive environment. This serves as the driving force for a number of innovative strategic changes in many organizations. To cope with the changing expectations of the organization, there is a need for continuous improvement of the organizational performance. Different innovations can be integrated to keep the performance above the competitors of all time. In enhancing the performance of any organization, in doing this effectively, the factors that drive such performance have to be well understood.

Knowledge Management (KM) practices have been used for improving the performance of many organizations (McKeen \& Singh, 2009). Sirvanci (2004) cited that higher-education institutions (HEIs) are the knowledge base with research and teaching/learning as the fundamental functions. It is ironical that HEls have been lagging behind other organizations in adopting and embracing this paradigm. In our modern world popularly referred to as the information age, knowledge is the key resource in this era. The problem today is not how to find the information, but how to manage it; the most important challenge for organizations is how to process knowledge and to make it profitable in the recent knowledge-driven organization (Sallis \& Jones, 2002). Thus, KM today is attracting great attention in both business and academic realms (McKeen \& Singh, 2009). Organizations are viewing KM as a critical success factor in today's dynamic environment (Ju, Lin, Lin \& Kuo, 2006; Yeh \& Ta, 2005).

Wang (2007) claimed that the KM practice could help organizations in many areas like employee's training, project management, team communication and organizational performance. Understanding the link between $\mathrm{KM}$ and organizational performance is important for successful integration of KM into organizational strategy (Carlucci \& Schiuma, 2006). Similarly, Daud, AbdulRahim and Alimun, (2008) emphasized that organizations should have the ability to convey knowledge from one unit/department to another to achieve an overall performance at the minimum possible cost.

\section{Problem Statement}

Like other sectors, the educational sector is also affected by the rapid changes in the business environment. According to Amin (2006), profound changes resulting from the emerging competitive business environment have made HEls and universities to think the same way like business organizations. Meanwhile, educational markets are becoming global. Based on this fact, ability to compete and stay in business under such a condition depends largely on how the changes and improvement are managed by educational institutions.

Jordanian HEls have suffered several problems, especially those related to lower performance. According to The International Arab Conference on Quality Assurance in Higher Education (2012), the final report revealed that the HEls are the most important aspects of any society. Therefore, what make the HEls to function are the teaching faculties. It was further noted that Jordanian HEls had suffered more than necessary in terms of the curricula, resources, teaching methods, modern technology and research. This thereby calls for an urgent improvement in the performance of the Jordanian higher educational organizations. 
Jordanian HEls have been going through a series of reforms to face the challenges that hinder the performance improvement. In addition, the society needs for applying researches, skilled workforce, and variety of educational services. On the other hand, the number of students and research fields are increasing constantly. From KM literature, it has been generally revealed that most of the KM-performance studies (e.g., Anantatmula, 2007; Safa, Shakir, \& Boon, 2006; Zack, McKeen, \& Singh, 2009) have only been carried out in developed countries such as United States, Australia, and European countries. There are very limited empirical studies that have been conducted in developing countries (Muhammad et al., 2011). This study opens up research opportunities to fill this gap.

KM in Jordanian HEls is still a recent application, but its possibility of acceptance is high. The fact is the universities are knowledgeable organizations (Alryalat \& Alhawari, 2008). However, the authors emphasized that the role of $\mathrm{KM}$ in improving the performance of Jordanian HEls needs further studies. Hence, it is necessary to conduct extensive studies on the impact of the KM processes in higher education. Given the above reasons, this study will investigate the following aspects: the theoretical and empirical evidence that established the relationship between, KM, and organizational performance; and the practical aspect, that is, how KM impact on organizational performance in the Jordanian higher-education context.

The research question for this study is:

1) Does Knowledge Management affect Organizational Performance at Jordanian HEls?

\section{Literature Review}

On this section, the researcher will review Knowledge Management (KM) and at the same time, a review of organizational performance is carried out for proper justification of the study.

\section{Organizational Performance (OP)}

The growing challenges to the organization in either attaining or sustaining competitive advantage have made an organizational performance to gain serious attention to survive in such a highly competitive environment. As a result, organizational performance is considered as an important construct in achieving the aim of the organization activities (Richard, Devinney, Yip \& Johnson., 2009). Conventionally, OP is narrowly viewed from the financial performance perspective, giving considerations to assets, budgets, sales volume, revenues growth or profitability results (Liao \& Wu, 2009). However, recent findings show that the nexus of OP goes beyond financial benefits such as competitive advantage, innovation, quality result, improvement trends, etc. (Kirby, 2005). Accordingly, this will lead to the following definition where OP is defined as a broad construct, which captures what organizations are involved in, produce, and accomplish for the various constituencies with which they interact.

\section{Organizational Performance Indicators in HEls}

The higher-education industry worldwide is facing a dynamic and unstable environment due to tendencies such as changing demographics in students" population, decrease in public funding and the greater importance of information and communication technology in learning and teaching 
process (Conway, 2003). It is believed that knowing such performance indicators will enable the organizations to achieve an acceptable level of OP.

Although the concepts of performance measurement have existed for many years, there is an increasing demand that agencies began to transform their organizations to institutionalize these practices (Poister, 2003). HEls also have to adjust themselves and develop strategies to respond rapidly to the changes in the organizational environment and increasing demands of stakeholders. Meanwhile, the criteria of key performance indicators (KPIs) in HEls should be built upon the set of interrelated concepts and values (Suryadi, 2007):

- Learning-centered education

- Organizational/personal learning

- Valuing faculty and academic staff

- HEI agility

- Focus on the growth and sustainability

- Innovation managing

According to Kanji and Tambi (1999), the performance indicators in HEls can be measured based on objective's achievement; this has to do with how well the core process (educational process) is operating.

\section{KM in Higher Education}

In this information era, virtually all organizations are becoming knowledge-driven in order to achieve or maintain the competitive advantage. Choy (2006) revealed that KM has been practiced in 80 percent of the most prominent companies in the world. The author concluded that the power of KM in an organization could not be overestimated considering the fact that for an organization to maintain her growth and development; there must be a regular update of the organizational knowledge.

$\mathrm{KM}$ in education can be defined as such a tool that gives clues to managers and staffs of educational organizations in the emerging world of KM to meet the challenge of the knowledge era. KM helps educational organizations to realize the merits and beauty of knowledge creation and sharing as a means of enhancing teaching and learning process.

In general, people refer to colleges and universities as knowledge environments. All their organizational activities (such as teaching, research and community service) revolve around knowledge. Such notion has been supported by many authors, for example, Kidwell, Linde, and Johnson (2000) revealed that knowledge being the hub of any higher institution of learning, and hence, educational organizations should take the advantage of the emerging field of KM to enhance innovation, promoting good customer service and gaining competitive advantage over their competitors. The authors buttressed this by the following quotation: "colleges and universities have significant opportunities to apply KM processes to support every part of their mission". In Jordanian HEls context, the efforts are continuing in order to remove obstacles and problems facing the development of the educational process (Alhammad, Faori \& Abu Husan, 2009). As a result of this status, and although KM practices in Jordanian higher education is still a new concept, the higher education sector responds positively to these practices in individual level and institutional level (Alhawary et al. 2011). 


\section{KM Dimensions}

Based on many researchers (Kiessling et al., 2009; Liao \& Wu, 2009; and Others), the researcher considers knowledge identification, knowledge discovery as a single dimension to be referred to as knowledge identification. And the other four main processes of KM, which are the acquisition, storage, sharing, and application to make a total of five processes (dimensions) of KM to be considered in this study. A discussion of the five dimensions of KM follows subsequent subsections.

\section{Knowledge Identification}

Knowledge identification is an action of discerning the location and value of knowledge, restraints to knowledge flow, and opportunities to leverage the value of knowledge. Tripathy, Patra, and Pani (2007) revealed that the knowledge identification is essential to know what knowledge the organization and its members are required in order meeting their goals and objectives. Thus, knowledge identification is significant in any organization for effective decision-making in order to gain a competitive advantage.

\section{Knowledge acquisition}

Once needed knowledge is identified, it has to be acquired for utilization. Thus, acquisition processes are those oriented to obtain the needed knowledge from both internal and external sources and formalize and document the obtained knowledge (Stollberg et al., 2004; Mohammad, Hamdeh \& Sabri, 2010). This requires access to knowledge in knowledge-based resources to capturing the new knowledge and exploiting the available knowledge.

\section{Knowledge Storage}

It is generally believed that if knowledge is valuable, then storing such valuable assets should be given an utmost concern. After acquiring knowledge, it is expected to be coded and recorded to enable easy access to such knowledge (Kiessling, Richey, Meng \& Dabic, 2009). Typically, some group of experts within the organization is responsible for refreshing and refining the organization-evolving reservoir of knowledge.

\section{Knowledge Sharing}

Knowledge sharing involves the exchange of information and knowledge from one source (person, group or organization) to another (Liao \& Wu, 2009). Therefore, knowledge sharing as a vital pillar of $\mathrm{KM}$ is critical to organizational performance in this knowledge era, and its full value needs to be tapped.

\section{Knowledge Application}

Within KM context, the concept of "application" has another interpretation, sometimes in literature where it is referred to as "utilization". Many researchers stated that knowledge application process denotes actual utilization of the knowledge (Asoh et al., 2007; Lee et al., 2005; Liao \& Wu, 2009; Zack, 1999). 


\section{Relationship between KM and OP}

Only a few researchers have studied the impact of KM on OP despite the global view that the rate of knowledge acquisition in an organization will determine its performance (Safa et al., 2006). The insinuation about the potential impact of KM on OP is derived from KM"s ability to create competitive advantage (Schulz \& Jobe, 2001). This among others has made KM to be identified as a strategic resource in the design and implementation of organizational strategy. Zack et al. (2009) equally posited that KM processes are directly related to OP. Levett and Guenov (2000) also revealed that KM practices being an ingredient of organizational performance. In the same vein, RubensteinMontano et al. (2001) as well supported this view. According to Zack et al. (2009), there is a paucity of empirical studies, which investigate the relationship between KM and OP.

\section{Methodology \\ Research Design}

To assess the level of application of knowledge management in the Jordanian Universities, the methodology of the primary research is selected. A questionnaire which is developed by Deshpande et al. (1993) for a similar research is used for this research. The questionnaire was served to a convenience sample of 70 academics in Jordanian Universities. The nature of the data is qualitative, hence, the respondents will be asked to rate their organizations on a scale of 1 to 5 with respect to knowledge management and from 1 to 3 with respect to performance.

\section{Research Instrument}

After going through the literature review and the scales developed by a number of researchers, the research instrument of Deshpande et al.(1993) was chosen since it seemed comprehensive and manageable in given context. Moreover, it was found that this instrument has used many western types of research successfully producing the valid results. Its two parts have been selected one is related to knowledge management comprising 9 questions whereas the second part is for measuring the organizational performance which is based on 4 questions. The knowledge management part is to be measured by on a scale of 1 to 5 while organizational performance part has a scale of 1 to 3 .

\section{Findings}

This study is aimed at indicating the relation between Knowledge Management and Organizational Performance. Various elements of Knowledge Management were probed and their average score was used as a single variable termed as Market Orientation.

Table 1. shows the means and standard deviations of all the variables in a summarized form.

\begin{tabular}{|l|l|l|}
\hline Variable & Mean & Std. Deviation \\
\hline Knowledge Management & 3.6221 & .91134 \\
\hline Organizational Performance & 2.104 & .82927 \\
\hline
\end{tabular}


INTERNATIONAL JOURNAL OF ACADEMIC RESEARCH IN BUSINESS AND SOCIAL SCIENCES

Vol. 8, No. 12, Dec, 2018, E-ISSN: 2222-6990 @ 2018 HRMARS

Table 2. Reliability Statistics

\begin{tabular}{|l|l|c|}
\hline Cronbach's Alpha & $\begin{array}{l}\text { Cronbach's Alpha Based on } \\
\text { Standardized Items }\end{array}$ & N of Items \\
\hline .957 & .959 & 13 \\
\hline
\end{tabular}

The Cronbach's alpha is .957 which is excellent as per Sekaran \& bougie (2010) which ensures the internal consistency of the response.

Table 3. Correlations

\begin{tabular}{|c|c|c|c|}
\hline & & $\begin{array}{l}\text { Knowledge } \\
\text { Management }\end{array}$ & $\begin{array}{l}\text { Organizational } \\
\text { Performance }\end{array}$ \\
\hline Knowledge Management & $\begin{array}{l}\text { Pearson } \\
\text { Correlation } \\
\text { Sig. (2- } \\
\text { tailed) } \\
\mathrm{N}\end{array}$ & $\begin{array}{l}1 \\
63\end{array}$ & $\begin{array}{l}.766^{* *} \\
.000 \\
63\end{array}$ \\
\hline Organizational Performance & $\begin{array}{l}\text { Pearson } \\
\text { Correlation } \\
\text { Sig. (2- } \\
\text { tailed) } \\
\mathrm{N}\end{array}$ & $\begin{array}{l}.766^{* *} \\
.000 \\
63\end{array}$ & $\begin{array}{l}1 \\
63\end{array}$ \\
\hline
\end{tabular}

**. Correlation is significant at the 0.01 level (2-tailed).

Table 3 shows the correlation between Knowledge Management and Organizational Performance. The coefficient of correlation is 0.766 positive which means there is a strong positive relationship between the two variables.

\section{Conclusion \& Recommendations}

This study examines the relationship between Knowledge Management and HEls performance using a sample of Universities from Jordan. The finding of the study shows that there is a positive and significant relationship between Knowledge Management and HEls performance of Jordan. The finding from the present study will benefit other Universities in Jordan and other countries various arms of government and will also serve as a frame of future research. Future research should consider 
INTERNATIONAL JOURNAL OF ACADEMIC RESEARCH IN BUSINESS AND SOCIAL SCIENCES

Vol. 8, No. 12, Dec, 2018, E-ISSN: 2222-6990 ¿ 2018 HRMARS

a longitudinal survey that will cover the entire geographical zones in Jordan. A qualitative design is suggested in order to explore in depth on the cause and effect relationship.

Acknowledgment

Authors would like to thank all those who have assisted in providing references so that the completion of this paper. 
INTERNATIONAL JOURNAL OF ACADEMIC RESEARCH IN BUSINESS AND SOCIAL SCIENCES

Vol. 8, No. 12, Dec, 2018, E-ISSN: 2222-6990 C 2018 HRMARS

\section{References}

Alhammad, F, Faori, S. \& Abu Husan, L. (2009). Knowledge sharing in the Jordian Universities, Journal of Knowledge Management Practice, Vol.10, No. 3.

Amin, N. W. G. (2006). Higher education in Sudan and knowledge management applications. Information and Communication Technologies, 1, 60-65.

Anantatmula, V. S. (2007). Linking KM effectiveness attributes to organizational performance. The Journal of Information and Knowledge Management Systems, 37(2), 133-149.

Asoh, D. A., Belardo, S., \& Crnkovic, J. (2007). Assessing knowledge management: Refining and cross validating the knowledge management index using SEM techniques. International Journal of Knowledge Management, 3(2), 1-30.

Carlucci, D., \& Schiuma, G. (2006). Knowledge asset value spiral: Linking knowledge assets to company performance. Knowledge and process Management, 13(1), 35-46.

Choy, S. C. (2006). Critical success factors to knowledge management implementation: A holistic approach. Paper presented at the Knowledge Management International Conference and Exhibition, Kuala Lumpur, Malaysia.

Conway, G. P. (2003). Higher education trends in the 21st century. Retrieved from available online at http://www.degreeinfo.com/article11_1.html.

Daud, S., AbdulRahim, R. E., \& Alimun, R. (2008). Knowledge creation and innovation in classroom. World Academy of Science, Engineering and Technology (39), 241-245.

Deshpandé, R., Farley, J. U., \& Webster Jr, F. E. (1993). Corporate culture, customer orientation, and innovativeness in Japanese firms: a quadrad analysis. The journal of Marketing, 23-37.

IACQA 2012: The International Arab Conference on Quality Assurance in Higher Education.

Ju, T., Lin, B., Lin, C., \& Kuo, H.-J. (2006). TQM critical factors and KM value chain activities. Total Quality Management, 17(3), 373-393.

Kanji, G. K., \& Tambi, A. M. (1998). Total quality management and higher education in Malaysia. Total Quality Management, 9(4/5), 130-132.

Kidwell, J. J., Vander Linde, K. M., \& Johnson, S. L. (2000). Applying corporate knowledge management practices applying corporate in higher education. Educause Quarterly(4), 28-33. 
INTERNATIONAL JOURNAL OF ACADEMIC RESEARCH IN BUSINESS AND SOCIAL SCIENCES

Vol. 8, No. 12, Dec, 2018, E-ISSN: 2222-6990 C 2018 HRMARS

Kidwell, J. J., Vander Linde, K. M., \& Johnson, S. L. (2000). Applying corporate knowledge management practices applying corporate in higher education. Educause Quarterly(4), 28-33.

Kiessling, T. S., Richey, R. G., Meng, J., \& Dabic, M. (2009). Exploring knowledge management to organizational performance outcomes in a transitional economy. Journal of World Business(44), 421-433.

Kirby, J. (2005). Toward a theory of high performance. Harvard Business Review, 83, 30-39.

Lee, K. C., Lee, S., \& Kang, I. W. (2005). KMPI: Measuring knowledge management performance. Information \& Management, 42, 469-482.

Levett, G. P., \& Guenov, M. D. (2000). A methodology for knowledget management implementation. Journal of Knowledge Management, 4(3), 258-269.

Liao, S.-h., \& Wu, C.-c. (2009). The relationship among knowledge management, organizational learning, and organizational performance. International Journal of Business and Management, 4(4), 64-76.

McKeen, J. D., Zack, M. H., \& Singh, S. (2006). Knowledge management and organizational performance: An exploratory survey. Paper presented at the 39th Hawaii International Conference on System Sciences, Hawaii.

Mohammad, A. H., Hamdeh, M. A., \& Sabri, A. T. (2010). Developing a theoretical framework for knowledge acquisition. European Journal of Scientific Research, 42(3), 453-463.

Muhammad, N., Rahman, B. A., Abd Rahman, W. Z., Idris, A. R., Sabri, S. M., \& Jusoff, K. (2011). Knowledge management practices (KMP) and academic performance in Universiti Teknologi Mara (UITM) Terengganu, Malaysia. World Applied Sciences Journal, 12(Special Issue on Creating a Knowledge Based Society), 21-26.

Poister, T. H. (2003). Measuring performance in public and nonprofit organizations. San Francisco: John Wiley \& Sons, Inc.

Richard, P. J., Devinney, T. M., Yip, G. S., \& Johnson, G. (2009). Measuring organizational performance: Towards methodological best practice. Journal of Management, 35(3), 718-804.

Rubenstein-Montano, B., Liebowitz, J., Buchwalter, J., McCaw, D., \& Newman, B. K. (2001). A systems thinking framework for knowledge management. Decision Support Systems(31), 5-16.

Safa, M. S., Shakir, F., \& Boon, O. K. (2006). Knowledge management: Practice and performance of NGO in Maldives. International Journal of Management and Entrepreneurship, 2(1), 69-86. 
INTERNATIONAL JOURNAL OF ACADEMIC RESEARCH IN BUSINESS AND SOCIAL SCIENCES

Vol. 8, No. 12, Dec, 2018, E-ISSN: 2222-6990 C 2018 HRMARS

Sallis, E., \& Jones, G. (2002). Knowledge management in education: Enhancing learning \& education. London, UK: Kogan Page Ltd.

Schulz, M., \& Jobe, L. A. (2001). Codification and tacitness as knowledge management strategies: An empirical exploration. The Journal of High Technology Management Research, 12(1), 139-165.

Sekaran, U., \& Bougie, R. (2010). Research methods for business (fifth ed.). UK: John Wiley \& Sons Ltd.

Sirvanci, M. B. (2004). TQM implementation: Critical issues for TQM implementation in higher education. The TQM Magazine, 16(6), 382-386.

Stollberg, M., Zhdanova, A. V., \& Fensel, D. (2004). H-TechSight- A next generation knowledge management platform. Journal of Information and Knowledge management, 3(1), 47-66.

Suryadi, K. (2007). Framework of measuring key performance indicators for decision support in higher education institution. Journal of Applied Sciences Research, 3(12), 1689-1695.

Tripathy, J. K., Patra, N. K., \& Pani, M. R. (2007). Leveraging knowledge management: Challenges for the information professional. DESIDOC Bulletin of Information Technology, 27(6), 65-73.

Wang, T. H. (2007). What strategies are effective for formative assessment in an e-learning environment? Journal of Computer Assisted Learning, 23(3), 171-186.

Yeh, Y. M. C., \& Ta, Y. (2005). The Implementation of knowledge management system In Taiwan"s higher education. Journal of College Teaching \& Learning, 2(9), 35-41.

Zack, M., McKeen, J., \& Singh, S. (2009). Knowledge management and organizational performance: An exploratory analysis. Journal of Knowledge Management, 13(6), 392-409. 